\author{
G.A. Yessenbayeva ${ }^{1}$, D.N. Yesbayeva ${ }^{2}$, T.Kh. Makazhanova ${ }^{1}$ \\ ${ }^{1}$ Ye.A.Buketov Karaganda State University, Kazakhstan; \\ ${ }^{2}$ Shanghai Factory-Amigo EC Technology Co., Ltd, China \\ (E-mail:esenbaevagulsima@mail.ru)
}

\title{
On the calculation of the rectangular finite element of the plate
}

\begin{abstract}
The article is devoted to the study of the thin plate bending by the finite element method. The application of the finite element method to solving the problem of the plate bending leads to the necessity of studying the rectangular finite element of the plate. All deformation and statics characteristics of the plate are functions of the displacement in the direction of the normal to the middle surface of the plate, which is determined by the deflection function. In the article, the formation of the plate deflection function in explicit form is carried out. The ways for finding the deflection function by division of the variables in the equilibrium equation of the plate, through an incomplete fourth-degree polynomial and in the form of Hermite polynomials are presented. The article is focused mainly on mechanics, engineers and scientific employees of technical specialties.
\end{abstract}

Keywords: finite element method, rectangular finite element, deflection function, angular displacements, Hermite polynomials

Introduction. Thin-walled structures are encountered in many branches of technology, such as civil, mechanical, aeronautical, marine, and chemical engineering. Such a widespread use of plate and shell structures arises from their intrinsic properties. When suitably designed, even very thin plates, and especially shells, can support large loads. Thus, they are utilized in structures such as aerospace vehicles in which light weight is essential.

One of the elements of thin-walled structures is a plate, which has an independent and wide application. Plates represent principal elements of aerospace structures, including fuselages of planes and missiles, control surfaces, bulkheads, helicopter blades, and others. In construction, the plates are widely used in the form of decking and panels, reinforced concrete slabs for coating industrial and residential buildings, slabs for foundations of massive structures and etc.

Mathematical models of calculating plates, closely related to the study of applied problems, have acquired special relevance in connection with the expanding volume of their applications in various fields of science and technology. The multiple applications, shapes, and materials found in plate structures dictate the necessity of a comprehensive approach to their analysis reflected in relevant theories and methodologies. Therefore, questions related to theoretical studies of the work of plates remain significant and relevant [1].

At calculation of plates by analytical methods in the most general formulation (with arbitrary contour supports (including elastic supports), with different types of loading) one has to face big mathematical difficulties, and in the majority of cases it is not possible to receive the analytical solution. It is possible to solve such a problem using a very efficient finite element method, which for plates is a numerical approximate method, but gives a sufficiently high accuracy of solutions.

The finite element method usually abbreviated as FEM is a numerical technique to obtain approximate solution to physical problems. FEM was originally developed to study stresses in complex aircraft structures; it has since been extended and applied to the broad field of continuum mechanics, including fluid mechanics and heat transfer and also mechanics of deformable solids and structural mechanics. Because of its capability to handle complex problems and its flexibility as an analysis tool, FEM has gained a prominent role in engineering analysis and design.

The name of this method to some extent predetermines its essence: when using the finite element method, the calculated design is mentally divided into separate elements, the stress-strain state of which is previously studied in detail and can be considered known. It is supposed that the elements are connected to each other at a finite number of points, called nodes. At these points, forces characterizing the interaction of individual elements, or displacements, through which, ultimately, the stresses and displacements of each element are calculated, are determined. Thus, the problem is discretized and reduced to solving a system of algebraic equations with respect to unknown forces or node displacements. FEM is characterized by a variational formulation, a discretization strategy, one or more solution algorithms and post-processing procedures [2]. 
According to the method of obtaining the basic resolving equations, the finite element method has four main types: the direct method, the variational method, the weighted residual method and the energy balance method.

Depending on what values are taken as unknown, there are three classical approaches used in FEM: the force method, the displacement method and the mixed method. We note that due to a number of advantages, the approach based on the idea of the displacement method is the most widespread in the FEM [3].

Replacement of the original construction by a set of discrete elements makes it possible to simplify the calculation of various construction objects: rod systems, thin-walled and massive structures and real structures in which rods, plates, shells, arrays are combined. This circumstance makes the finite element method very universal and explains its increased popularity.

Moreover, the advantage of the finite element method is a comparatively simple implementation on a PC with the help of a software package. At the same time, it is easy to set any boundary conditions of the plate on the contour, including elastic ones, and various types of load.

Depending on the type of the considered construction, the type of the finite element is determined. So for rod systems rods with different supports at the ends, representing the nodes of the element, can be taken as a finite element. Thin-walled spatial systems consisting of plates and shells are divided into triangular, rectangular or elements of any other shape with nodes at angular points. Next, we focus on the consideration of rectangular finite elements and their application in the calculations of plates.

Bending of thin plates. We consider the problem of calculating thin rigid plates. Their thickness should not exceed the $\frac{1}{5}$ of smallest side of the plate, and the deflection in bending should not exceed the thickness $h$ (Fig. 1, a). On the basis of Kirchhoff-Lyava's hypotheses about the smallness of the normal stresses, perpendicular to the middle surface of a plate, and the smallness of direct normals to the same surface the technical theory of a bending of thin plates is constructed [4].

The assumptions derived from accepted hypotheses can be formulated as follows:

1. Normal stresses $\sigma_{z}$ and also tangential stresses $\tau_{x z}, \tau_{y z}$ are negligibly small in comparison with stresses which are considered as the main: $\sigma_{x}, \sigma_{y}, \tau_{x y}$ (Fig. 1, b). Therefore, we accept $\sigma_{z}=\tau_{x z}=\tau_{y z}=0$.
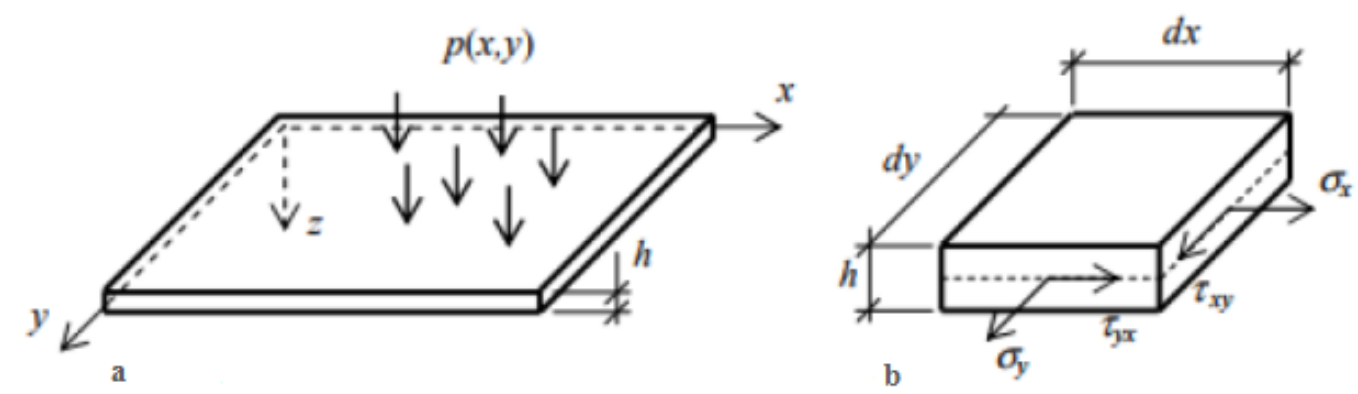

Figure 1. The thin plate

2. The displacements in the direction of the axis $z$ are constant along the thickness of the plate and are equal to the deflections of the middle surface, which does not deform in its plane. At the same time the external load must be perpendicular to the plate surface, that is, to the $x y$ coordinate plane.

These assumptions simplify the mathematical model of plate bending, reducing it to a two-dimensional problem. All deformation and statics quantities of the plate are functions of only one unknown, namely the displacement in the direction of the normal to the middle surface of the plate.

However, unlike a plane problem, as a classical two-dimensional problem, the deflections of a plate are described by a fourth order differential equation, but not of the second order, deformations are derivatives of displacements of the second, but not of the first order. Thus, in the expression for the potential energy functional, second-order derivatives also appear. When using the finite element method, this leads to some difficulties related to the approximation of the deflection function $w(x, y)$.

Firstly, the approximating polynomials used in the bending of plates are much more complicated than for the plane problem of the theory of elasticity, besides, their form is not unique for a particular finite element. For example, for a deflection function, a fourth-degree polynomial with twelve indefinite coefficients can contain different terms, which in turn leads to different stiffness matrices for the elements.

Secondly, the conditions of compatibility between adjacent elements must be fulfilled not only for the function of deflections, but also for its first derivatives. Nevertheless, in practice incompatible finite elements, 
in which continuity on the boundaries between elements is performed only for deflections, are often applied. For example, such an element is a four-node rectangular finite element with twelve degrees of freedom, which provides acceptable accuracy of the solution and is used to calculation of plates having a rectangular shape [3].

The deflection function of a finite rectangular element. We select a rectangular finite element $0<x_{1}<a$, $0<x_{2}<b$ from the plate and consider it in the local coordinate system $\left(x_{1}, x_{2}\right)$.

We number knots of a rectangular final element consistently (clockwise, starting from the upper left node) and introduce new coordinates $x, y$ so that $x=\frac{x_{1}}{a}, y=\frac{x_{2}}{b}$. The deformed state is completely determined by nodal displacements. In each node $i(i=1,2,3,4)$ of the finite element, there are three displacements: $w_{i}$ is a deflection, $\varphi_{x i}$ is an angle of rotation along the axis $x, \varphi_{y i}$ is an angle of rotation along the axis $y$ (Fig. 2).

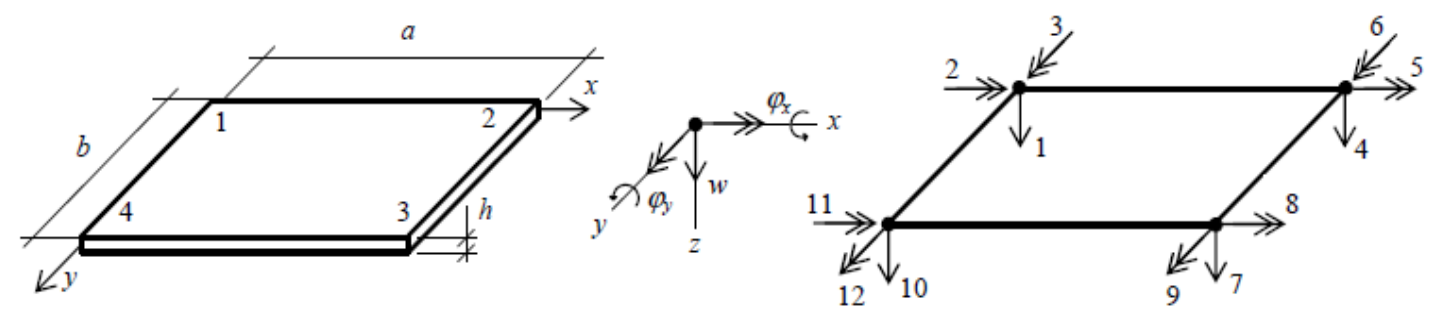

Figure 2. Displacements of the finite element in the nodes

Angular displacements are defined in terms of partial derivatives of the deflection function as follows

$$
\varphi_{x}=\frac{\partial w}{\partial x}, \quad \varphi_{y}=\frac{\partial w}{\partial y} .
$$

To determine the deflection function of the finite element, we use the equation of plate equilibrium in the absence of a transverse external load

$$
\nabla^{2} \nabla^{2} w=0 .
$$

We search the solution of equation (2) in the form

$$
w(x, y)=X(x) Y(y) .
$$

Substituting (3) into (2) we obtain an equation which is divided into three independent equations

$$
X^{I V}=0, \quad X^{\prime \prime} Y^{\prime \prime}=0, \quad Y^{I V}=0 .
$$

The first and the third equations are the bending equations for mutually perpendicular beams. The solutions of the first and the third equations (4) in the coordinate functions have the form

$$
\begin{aligned}
& X(x)=f_{1}(x) z_{i}+f_{2}(x) \theta_{i}+f_{3}(x) z_{j}+f_{4}(x) \theta_{j} ; \\
& Y(y)=g_{1}(y) z_{k}+g_{2}(y) \theta_{k}+g_{3}(y) z_{l}+g_{4}(y) \theta_{l},
\end{aligned}
$$

where $i, j, k, l$ - are beam nodes; the values $z_{m}(m=i, j, k, l)$ are vertical displacements; $\frac{\theta_{i}}{a}, \frac{\theta_{j}}{a}, \frac{\theta_{k}}{b}, \frac{\theta_{l}}{b}-$ are angular displacements of the given beam. The beam coordinate functions for transverse bending have the values

$$
\begin{gathered}
f_{1}(x)=2 x^{3}-3 x^{2}+1, \quad f_{2}(x)=x^{3}-2 x^{2}+x, \\
f_{3}(x)=-2 x^{3}+3 x^{2}, \quad f_{4}(x)=x^{3}-x^{2} .
\end{gathered}
$$

The functions $g_{n}(y)(n=1,2,3,4)$ are obtained from the expressions (6) by replacing $x$ by $y$

$$
\begin{gathered}
g_{1}(y)=2 y^{3}-3 y^{2}+1, \quad g_{2}(y)=y^{3}-2 y^{2}+y \\
g_{3}(y)=-2 y^{3}+3 y^{2}, \quad g_{4}(y)=y^{3}-y^{2} .
\end{gathered}
$$

Substituting (5) into (3), we write down the deflection function of the finite element in the following form

$$
w(x, y)=\sum_{i, j=1}^{4} c_{i j} \xi_{i j}(x, y),
$$

where arbitrary constants $c_{i j}$ and functions $\xi_{i j}(x, y)$ have the form 


$$
\begin{gathered}
c_{11}=z_{i} z_{k}, \quad c_{12}=z_{i} \theta_{k}, \quad c_{13}=z_{i} z_{l}, \quad c_{14}=z_{i} \theta_{l}, \\
c_{21}=z_{k} \theta_{i}, \quad c_{22}=\theta_{i} \theta_{k}, \quad c_{23}=z_{l} \theta_{i}, \quad c_{24}=\theta_{i} \theta_{l}, \\
c_{31}=z_{j} z_{k}, \quad c_{32}=z_{j} \theta_{k}, \quad c_{33}=z_{j} \theta_{l}, \quad c_{34}=z_{j} z_{l}, \\
c_{41}=z_{k} \theta_{j}, \quad c_{42}=\theta_{j} \theta_{k}, \quad c_{43}=z_{l} \theta_{j}, \quad c_{44}=\theta_{j} \theta_{l} ; \\
\xi_{i, j}(x, y)=f_{i}(x) g_{j}(y), \quad i, j=1,2,3,4 .
\end{gathered}
$$

At the nodes of the finite element, we have the following boundary conditions

$$
\begin{gathered}
w\left(\alpha_{i}, \beta_{i}\right)=w_{i}, \quad \varphi_{x}\left(\alpha_{i}, \beta_{i}\right)=\lambda_{i}, \quad \varphi_{y}\left(\alpha_{i}, \beta_{i}\right)=\mu_{i}, \quad i=1,2,3,4, \\
\alpha_{1}=\alpha_{4}=0, \quad \alpha_{2}=\alpha_{3}=1, \quad \beta_{1}=\beta_{2}=0, \quad \beta_{3}=\beta_{4}=1 .
\end{gathered}
$$

The values $w_{1}-w_{4}$ - are the linear displacements of the finite element; $\lambda_{1}-\lambda_{4}-$ are angular displacements of nodes of a finite element along the axis $x ; \mu_{1}-\mu_{4}$ - are the angular displacements of the nodes of the element along the axis $y$.

Defining the derivatives (1) of the function (8) and substituting them and the function (8) in turn into the boundary conditions (11), we obtain the values of the arbitrary constants (9) in the form

$$
\begin{aligned}
c_{m_{i}, n_{i}}=w_{i}, & c_{p_{i}, n_{i}}=\lambda_{i} a, \quad c_{m_{i}, p_{i}}=\mu_{i} b, \quad i=1,2,3,4 \\
m_{1}=m_{4}=n_{1}=n_{2}=1, & p_{1}=p_{4}=2, \quad m_{2}=m_{3}=n_{3}=n_{4}=3, \quad p_{2}=p_{4}=4 .
\end{aligned}
$$

Thus, twelve of the sixteen arbitrary constants from the boundary conditions (11) are calculated.

To determine the remaining four arbitrary constants, we use the second equation in (4) and introduce the denotation

$$
\eta(x, y)=X^{\prime \prime}(x) Y^{\prime \prime}(y)
$$

For the function $\eta(x, y)$, from (4) we have the following boundary conditions at the nodes of the finite element

$$
\eta\left(\alpha_{i}, \beta_{i}\right)=0, \quad i=1,2,3,4 .
$$

Having determined the second derivatives of (5) and computing their products by (13), and then substituting in (14) we obtain the following system of equations.

We calculate the second derivatives of (5) and their products by (13). Then substituting these expressions into (14), we obtain the following system of equations

$$
\left\{\begin{array}{l}
4 c_{22}+2 c_{24}+2 c_{42}+a_{44}=-d_{1} \\
2 c_{22}+c_{24}+4 c_{42}+2_{44}=d_{2} \\
2 c_{22}+4 c_{24}+c_{42}+2 a_{44}=d_{3} \\
c_{22}+2 c_{24}+2 c_{42}+4 a_{44}=-d_{4}
\end{array}\right.
$$

where the free terms expressed in terms of the known coefficients (12) take the following values

$$
\begin{gathered}
d_{1}=9 c_{11}+6 c_{12}-9 c_{13}+3 c_{14}+6 c_{21}-6 c_{23}-9 c_{31}+6 c_{32}+9 c_{33}-3 c_{34}+3 c_{41}-3 c_{43} ; \\
d_{2}=-9 c_{11}-6 c_{12}+9 c_{13}-3 c_{14}-3 c_{21}+3 c_{23}+9 c_{31}+6 c_{32}-9 c_{33}+3 c_{34}-6 c_{41}+6 c_{43} ; \\
d_{3}=-9 c_{11}-3 c_{12}+9 c_{13}-6 c_{14}-6 c_{21}+6 c_{23}+9 c_{31}+3 c_{32}-9 c_{33}+6 c_{34}-3 c_{41}+3 c_{43} ; \\
d_{4}=9 c_{11}+3 c_{12}-9 c_{13}+6 c_{14}+3 c_{21}-3 c_{23}-9 c_{31}+3 c_{32}+9 c_{33}-6 c_{34}+6 c_{41}-6 c_{43} .
\end{gathered}
$$

Solving the system of equations (15) and considering (16), we find the remaining arbitrary constants

$$
\left\{\begin{array}{l}
c_{22}=-c_{11}-c_{12}+c_{13}-c_{21}+c_{23}+c_{31}+c_{32}-c_{33} ; \\
c_{24}=-c_{11}+c_{13}-c_{14}-c_{21}+c_{23}+c_{31}-c_{33}+c_{34} ; \\
c_{42}=-c_{11}-c_{12}+c_{13}+c_{31}+c_{32}-c_{33}-c_{41}+c_{43} \\
c_{44}=-c_{11}+c_{13}-c_{14}+c_{31}-c_{33}+c_{34}-c_{41}+c_{43} .
\end{array}\right.
$$


Taking into account the values of the beam functions $(6),(7)$ and the values of the arbitrary constants (12), (17), we write the deflection function of the finite element (8) with regard to (10) in the following form

$$
\begin{aligned}
& w(x, y)=\vec{r}^{T} \vec{s} \\
& \vec{r}^{T}=\left[\begin{array}{llllllllllll}
r_{1} & r_{2} & r_{3} & r_{4} & r_{5} & r_{6} & r_{7} & r_{8} & r_{9} & r_{10} & r_{11} & r_{12}
\end{array}\right] ; \\
& \vec{s}=\left[\begin{array}{llllllllllll}
w_{1} & \lambda_{1} & \mu_{1} & w_{2} & \lambda_{2} & \mu_{2} & w_{3} & \lambda_{3} & \mu_{3} & w_{4} & \lambda_{4} & \mu_{4}
\end{array}\right] .
\end{aligned}
$$

Here $\vec{r}^{T}$ is the transposed vector of the coordinate functions of the plate; $\vec{s}$ is the vector of nodal displacements of a rectangular finite element.

The coordinate functions of the plate have the form

$$
\begin{gathered}
r_{1}(x, y)=f_{1}(x)(1-y)+(1-x) g_{1}(y)-(1-x)(1-y), \quad r_{2}(x, y)=a f_{2}(x)(1-y), \quad r_{3}(x, y)=b(1-x) g_{2}(y) \\
r_{4}(x, y)=f_{3}(x)(1-y)-x g_{3}(y)+x y, \quad r_{5}(x, y)=a f_{4}(x)(1-y), \quad r_{6}(x, y)=b x g_{2}(y) \\
r_{7}(x, y)=f_{3}(x) y+x g_{3}(y)+x, \quad r_{8}(x, y)=a f_{4}(x) y, \quad r_{9}(x, y)=b x g_{4}(y) \\
r_{10}(x, y)=(1-x) g_{3}(y)-f_{3}(x) y+x y, \quad r_{11}(x, y)=a f_{2}(x) y, \quad r_{12}(x, y)=b(1-x) g_{4}(y)
\end{gathered}
$$

where $1-x, x, 1-y, y$ are the coordinate functions of the linear element (the rod) when the torsion is made in the direction of coordinate axes.

The same form (18) for the deflection function can be obtained if the solution of the equilibrium equation for plates (2) is sought in a more particular form

$$
w(x, y)=\sum_{i, j=1}^{4} c_{i j} f_{i}(x) g_{j}(y)
$$

where $c_{i j}$ are arbitrary constants to be determined; $f_{i}(x)$ and $g_{j}(y)$ are the beam coordinate functions for bending along the axes directions and, respectively. Arbitrary constants are defined in a manner similar to that described above. A complete calculation on finding the deflection function in the form (20) is presented in [5].

The proposed classical method of determining the deflection function allows to obtain this function in explicit form and to give a physical meaning for it. The analysis of the formulas (19) shows that the coordinate functions of the finite element of the plate are equal to the product of the coordinate function of the beam when it is bent to the coordinate function of the rod during torsion. Each coordinate function describes a finite element deformation caused by a single nodal displacement value. The final form of the defined deflection function depends on the coordinate beam functions in bending and on the coordinate functions of the rod (linear element) in torsion.

Thus, the method based on the General solution of the biharmonic equation (2) allows us to obtain the deflection function of a rectangular finite element in explicit form and to give it a vivid physical meaning: the deformation of the finite element of the plate is representable through deformations of the beam and the rod.

In the traditional approach, the deflection function is given as an incomplete fourth-degree polynomial. The following expression of the deflection function

$$
w(x, y)=\alpha_{1}+\alpha_{2} x+\alpha_{3} y+\alpha_{4} x^{2}+\alpha_{5} x y+\alpha_{6} y^{2}+\alpha_{7} x^{3}+\alpha_{8} x^{2} y+\alpha_{9} x y^{2}+\alpha_{10} y^{3}+\alpha_{11} x^{3} y+\alpha_{12} x y^{3}
$$

has certain advantages. In particular, along any line $x=$ const or $y=$ const the displacement $w(x, y)$ will change by cubic law. All external boundaries and boundaries between elements consist precisely of such lines. Since the third degree polynomial is uniquely determined by four constants, the displacements along the boundary are uniquely determined by the values of displacements and angles of inclination at the nodal points at the ends of this boundary. And since for adjacent elements the values at the ends of the boundary are the same, then along any boundary between finite elements the function $w(x, y)$ will be continuous.

Constants $\alpha_{1}, \ldots, \alpha_{12}$ are determined from a system of twelve equations relating the values $w(x, y)$ and angles of inclination at the node points, which are obtained as a result of substituting the coordinates of these points. Arbitrary constants are determined (is founded) by inversion of the twelfth order matrix or by other linear algebra methods [6].

As possible states, deflection functions can be adopted on the basis of Hermite polynomials, sometimes used in calculations by the finite element method in displacements. For example, in the case of a rectangular 
plate under arbitrary lateral load, the deflection function of a rectangular finite element can be represented as a polynomial of the fourth degree. Such a deflection function $w(x, y)$ can be obtained in the form of Hermite polynomials [1]

$$
\begin{gathered}
w(x, y)=z_{1} H_{01}(x) H_{01}(y)-z_{2} H_{11}(x) H_{01}(y)+z_{3} H_{01}(x) H_{11}(y)+z_{4} H_{02}(x) H_{01}(y)- \\
\quad-z_{5} H_{12}(x) H_{01}(y)+z_{6} H_{02}(x) H_{11}(y)+z_{7} H_{02}(x) H_{02}(y)+z_{8} H_{12}(x) H_{02}(y)+ \\
+z_{9} H_{02}(x) H_{12}(y)+z_{10} H_{02}(x) H_{02}(y)+z_{11} H_{12}(x) H_{02}(y)+z_{12} H_{02}(x) H_{12}(y),
\end{gathered}
$$

where the values of the nodal displacements $z_{1}, \ldots, z_{12}$ are equal to the followig values

$$
\begin{gathered}
z_{3 n-2}=w\left(\gamma_{n}, \delta_{n}\right), \quad z_{3 n-1}=-\frac{\partial w}{\partial x}\left(\nu_{n}, \omega_{n}\right), \quad z_{3 n}=\frac{\partial w}{\partial y}\left(\rho_{n}, \tau_{n}\right), \quad n=1,2,3,4 ; \\
\gamma_{1}=\gamma_{10}=\delta_{1}=\delta_{4}=\nu_{2}=\nu_{11}=\omega_{2}=\omega_{5}=\rho_{3}=\rho_{12}=\tau_{3}=\tau_{6}=0 ; \\
\gamma_{4}=\gamma_{7}=\nu_{5}=\nu_{8}=\rho_{6}=\rho_{9}=a, \quad \delta_{7}=\delta_{10}=\omega_{8}=\omega_{11}=\tau_{9}=\tau_{12}=b .
\end{gathered}
$$

Conclusion. The deflection function of a rectangular finite element determines uniquely the deformed state of an element by means of its nodal displacements. As it was said above, on the basis of the explicit shape of the deflection function, all necessary matrices (deformation, stress, stiffness and load) can be obtained. Note that the deflection function of the finite element forms the basis for calculating the plate by the finite element method. On its basis it is not difficult to develop an algorithm for calculation with the implementation on a PC.

\section{References}

1 Завьялов В.Н. Основы строительной механики пластин / В.Н. Завьялов, Е.А. Мартынов, В.М. Романовский. - Омск: СибАДИ, 2012. - 116 с.

2 Зенкевич О. Метод конечных элементов в технике / О. Зенкевич. - М.: Мир, 1975. - 541 с.

3 Лукашевич А.А. Современные численные методы строительной механики / А.А. Лукашевич. Хабаровск: Изд-во ХГТУ, 2003. - 135 с.

4 Александров А.В. Основы теории упругости и пластичности / А.В. Александров, В.Д. Потапов. М.: Высш. шк., 1990. - 400 с.

5 Турсунов К.А. Прямоугольный конечный элемент пластины / К.А. Турсунов, А.Е. Елешова // Труды университета. Раздел: Математика. Механика. - Караганда: Изд. КарГТУ. 2000. - Вып. 1(1). - C. 61-63.

6 Овчаренко В.А. Расчет задач машиностроения методом конечных элементов / В.А. Овчаренко. Краматорск: ДГМА, 2004. - 128 с.

\section{Г.А. Есенбаева, Д.Н. Есбаева, Т.Х. Макажанова}

\section{Пластинаның тікбұрышты соңғы элементін есептеу туралы}

Мақала соңғы элементтер әдісімен жіңішке пластинаның иілуін зерттеуге арналған. Пластинаның иілу есебін шешуге соңғы элементтер әдісінің қолданылуы пластинаның тікбұрышты соңғы элементін зерттеу қажеттілігіне әкеледі. Ауытқулар функциямен анықталатын, пластинаның барлық деформациясы және статикалық мәндері қалыпты бағытта пластинаның орта бетінде жылжу функциясы болып табылады. Мақалада пластиналардың ауытқулар функциясы айқын түрде қалыптастыру қарастырылды. Ауытқулар функциясы пластинаның тепе-теңдік теңдеуіндегі айнымалы мәндерді төртінші дәрежелі толық емес полиномдық және Эрмит полиномы түрінде бөлу арқылы табу әдісі берілген. Мақала негізінен механиктерге, инженерлер мен техникалық қызметкерлерге бағытталған.

Kiлm сөздер: соңғы элементтер әдісі, тікбұрышты соңғы элемент, ауытқулар функциясы, бұрыштық жылжу, Эрмит полиномы. 
Г.А. Есенбаева, Д.Н. Есбаева, Т.Х. Макажанова

\section{О расчете прямоугольного конечного элемента пластины}

Статья посвящена исследованию изгиба тонкой пластины методом конечных элементов. Приложение метода конечных элементов к решению задачи об изгибе пластины приводит к необходимости исследования прямоугольного конечного элемента пластины. Все деформационные и статические величины пластины являются функциями перемещения в направлении нормали к срединной поверхности пластины, которое определяется функцией прогибов. В статье приведено построение функции прогибов пластин в явном виде. Приведены способы нахождения функции прогибов разделением переменных в уравнении равновесия пластины, через неполный полином четвертой степени и в виде полиномов Эрмита. Статья ориентирована, главным образом, на механиков, инженеров и сотрудников технических специальностей.

Ключевые слова: метод конечных элементов, прямоугольный конечный элемент, функция прогибов, угловые перемещения, полиномы Эрмита.

\section{References}

1 Zavyalov, V.N., Martynov, E.A., \& Romanovsky, V.M. (2012). Osnovy stroitelnoi mekhaniki plastin [Fundamentals of structural plates mechanics]. Omsk: SibADI [in Russian].

2 Zenkevich, O. (1975). Metod konechnykh elementov v tekhnike [Finite element method in engineering]. Moscow: Mir [in Russian].

3 Lukashevich, A.A. (2003). Sovremennye chislennye metody stroitelnoi mekhaniki /Modern numerical methods of structural mechanics]. Khabarovsk: Izdatelstvo KhHTU [in Russian].

4 Aleksandrov, A.V., \& Potapov, V.D. (1990). Osnovy teorii upruhosti i plastichnosti [Fundamentals of elasticity and plasticity theory]. Moscow: Vysshaia shkola [in Russian].

5 Tursunov, K.A., \& Eleshova, A.E. (2000). Priamouholnyi konechnyi element plastiny [The rectangular finite plate element]. Trudy universiteta. Razdel: Matematika. Mekhanika-Proceedings of the University. Section: Mathematics. Mechanics. Karaganda: Publ. KarHTU, 1(1), 61-63 [in Russian].

6 Ovcharenko, V.A. (2004). Raschet zadach mashinostroeniia metodom konechnykh elementov [Calculation of mechanical engineering problems by finite element method]. Kramatorsk: DHMA [in Russian]. 